\title{
Correspondence
}

\section{Doctors and nurses in neonatal intensive care}

Sir,

Drs Chiswick and Roberton seem to propose a new deal for neonatal nurses, but are they not really hoping to maintain doctors in the hospital service in the lifestyle to which they have been accustomed ${ }^{1}$ The fact is that all acute hospital services, not only neonatal ones, demand 24 hour care by trained, and that means permanent, staff. The idea that the primary function of our hospitals is the training of doctors is out of date and should be put to rest. What other service or industry in this country discards many of its workers at the moment when they have been trained and could be of the greatest value? It is not unreasonable to suggest that the staffing structure of the great Victorian voluntary hospitals is not applicable to hospitals in the twenty first century.

\section{Reference \\ 1 Chiswick ML, Roberton NC. Doctors and nurses in neonatal intensive care: towards integration. Arch Dis Child 1987;62: 653-5.}

\section{H J LiebeschuETZ 45 Tyrone Road, Thorpe Bay, Essex SS1 3HE.}

Sir,

The case for allowing nurses to assume some of the duties of medical staff in the intensive care baby unit could be put in a less circumspect way than by Chiswick and Roberton though perhaps less tactfully. ${ }^{1}$ The problem of requiring more junior staff in a medical specialty than there are consultant posts eventually available for them is not new. Indeed it could be said to be an old tradition of United Kingdom postgraduate medical training. If this, for whatever reason, is no longer acceptable, the work of junior medical staff will either have to be taken over by additional consultants or by appropriately trained nurses.

Increasing the numbers of consultants is an expensive solution, condemning medical staff to a lifetime of working unsocial hours, and is a recipe for intractable personal rivalries within any one unit. On the other hand the sheer joy of employing nurses to do the work of junior medical staff would be boundless. A dedicated career nurse in such a position would avoid all the hassle of retraining medical novices every six months. She would work all hours, have no ambitions to replace the consultant, and by definition of work roles, she could not do so anyway. And on top of all that it would actually cost less money. To argue in this situation that the nurses' job would be more interesting is the kind of thing that gives male chauvinism a bad name.

Neonatal nurses could do worse than chat to their midwifery colleagues. Without the considerable practical skills and professional experience of midwives more obstetricians would have to be employed to spend their lives delivering babies at night, and daytime gynaecological practice would be under threat. Midwives have attained the level of practical indispensability that paediatricians would wish on their own senior nurses. Why then is there so much unrest among hospital midwives? And why so much talk of the days when they worked alone in people's homes?

\section{Reference}

1 Chiswick ML, Roberton NC. Doctors and nurses in neonatal intensive care: towards integration. Arch Dis Child 1987;62: 653-5.

A J BARSON

St Mary's Hospital for Women and Children, Whitworth Park, Manchester M13 OJH.

\section{Hospital medical staffing: achieving a balance}

Sir,

Our fears about the future of women doctors in paediatrics were confirmed on reading the British Paediatric Association's response to the consultative document, Hospital medical staffing: achieving a balance. Despite the intake of female medical students having been around $50 \%$ for the last decade, there is still a disproportionately small number of women reaching senior posts in a specialty recognised as popular with female doctors. While welcoming an attempt to redress the now serious problem of hospital staffing and career structure, the proposed new non-training intermediate grade seems to offer indefinite routine and emergency work to help distribute the amount of time spent on call. Experience has shown that such posts lead to frustration and loss of commitment with a deterioration in standards. We recognise that such posts would be desirable for a few female doctors but as members of the Medical Women's Federation we thoroughly agree with their policy, which is to advise any doctor strongly against taking one of these positions, though it may appear attractive in the short term at a time of heavy domestic commitments. Adequate part time training opportunities in posts equal in quality to those filled by full time doctors would serve the needs of these women better and lead to a higher standard of care in hospitals. Later they would be able to make a 
larger professional contribution in posts appropriate to their capabilities, and have a chance to influence departmental and hospital policies. At a time when specialist training is becoming more prolonged we see the increase in posts of senior house officer grade as giving us registrars by another name, and pushing the bottle-neck further down the career ladder.

If both foreign and British graduates are to be doing the same rotations, and if the posts are to be of equal quality, then the contracts must all be held at regional headquarters so that acceptable rotations can be organised. As a majority of registrars will eventually obtain consultant appointments in district general hospitals, we believe that it should be obligatory for all registrars to have at least two years' experience in such hospitals. Opportunities for overseas graduates to work in teaching hospitals should also be available.

Despite much time and thought having been given to the problem of hospital staffing in 1980-81, little progress had been made by 1985 . What has happened since then that could not have been foreseen? We now have imposed on us an ill thought out, hasty, and short sighted solution in a struggling hospital service, which remains unsympathetic to the requirements of flexibility that are now needed for $50 \%$ of medical school graduates, so that their full potential may be realised.

H P McDowell and J GREGG Royal Liverpool Children's Hospital, Alder Hey, Liverpool L12 2 AP

\section{Concern over safety of SAGM blood}

Sir,

We read with interest the letter from Drs Roberton and Chiswick. We recently carried out an exchange transfusion in a neonate using $500 \mathrm{ml}$ of partially packed SAGM blood. She was born at 38 weeks' gestation, weighed $3000 \mathrm{~g}$ at birth, and required an exchange transfusion for $\mathrm{ABO}$ group incompatibility when 19 hours old.

Before the transfusion the infant's total serum protein concentration was $58 \mathrm{~g} / \mathrm{l}$, and the serum albumin concentration was $36 \mathrm{~g} / \mathrm{l}$. These fell to $43 \mathrm{~g} / \mathrm{l}$ and $28 \mathrm{~g} / \mathrm{l}$, respectively, immediately after the transfusion. By the following day the patient's total serum protein concentration was $52 \mathrm{~g} / \mathrm{l}$ with a serum albumin concentration of 32 $\mathrm{g} / \mathrm{l}$. A coagulation screen immediately after the transfusion showed a prothrombin ratio of $1: 3$, a kaolin cephalin coagulation time of 39 seconds [control 38 seconds], and a prothrombin time of 22 seconds [control 19 seconds].

This infant tolerated a SAGM exchange transfusion with a temporary fall in plasma protein concentration and no disturbance of coagulation. Partially packed SAGM contains protein concentrations that are one third to one half of those of normal plasma. Though SAGM donor blood may be safe for use in exchange transfusions in the well term infant, further assessment is required in the ill low birthweight baby. Reference
${ }^{1}$ Roberton NRC, Chiswick ML. Concern over safety of SAGM
blood. Arch Dis Child 1987;62:638.

S W RYAN

Clarendon Wing,

Leeds General Infirmary,

Leeds

B BHADURI

York District Hospital,

York

M J HARRAN

York District Hospital,

York

\section{Peptic ulceration: long term outcome}

Sir,

Murphy et al reviewed 110 children with duodenal ulcers. ${ }^{1}$

We are carrying out a long term follow up study of 36 children with peptic ulcers. The clinical features are similar but the long term outcome is different. The aim of our study, begun in 1982 , was to determine endoscopically the healing rate after eight weeks of treatment with ranitidine, and the rate of relapse after stopping the drug. Endoscopy was repeated every six months or when symptoms recurred. For ethical reasons no placebo group was included.

The average number diagnosed annually was seven, the mean age at diagnosis was 9 years 7 months (range 18 months to 19 years), the male:female ratio was $1 \cdot 8: 1$ and the mean duration of symptoms before diagnosis two years four months. There was a family history of peptic ulcer in $47 \%$. The commonest symptoms were abdominal pain $(91 \%)$, vomiting $(47 \%)$, and bleeding $(11 \%)$. The maximal acid output after pentagastrin stimulation was two standard deviations above normal in $66 \%$. Of six patients with antral and prepyloric ulcers the maximal acid output was raised in five and normal in one, suggesting an identical pathogenetic factor. ${ }^{2}$

The table shows the sites of the ulcers, the rate of healing in 34 patients, and the rate of relapse in the 30 who were followed for more than a year. Though our series is smaller than that reported by Murphy et al, some of these preliminary data can be compared with his.

The main difference is in the rate of relapse $(36 \%$ compared with $70 \%$ ) and the length of time before relapse

Table Features of peptic ulcers in 36 patients

\begin{tabular}{lccc}
\hline Features of ulcers & $\begin{array}{l}\text { No of } \\
\text { boys } \\
(n=23)\end{array}$ & $\begin{array}{l}\text { No of } \\
\text { girls } \\
(n=13)\end{array}$ & $\begin{array}{l}\text { Total } \\
\text { No } \\
(n=36)\end{array}$ \\
\hline Site: & 18 & 10 & 28 \\
$\quad$ Duodenum & 5 & 3 & 8 \\
$\quad$ Antrum or prepyloric zone & $22 / 23$ & $10 / 11$ & $32 / 34$ \\
No healed after eight weeks & $9 / 21$ & $2 / 9$ & $11 / 30$ \\
No relapsed & & & \\
\hline
\end{tabular}

